\title{
PENYULUHAN TERKAIT KENORMALAN BARU ATAU NEW NORMAL PADA MASA PANDEMI COVID-19
}

\author{
Teresia Ivana $^{1^{*}}$, Warjiman ${ }^{2}$, Fransiska Dwi Hapsari ${ }^{3}$ \\ ${ }^{1}$ STIKES Suaka Insan, ${ }^{2}$ STIKES Suaka Insan, , ${ }^{3}$ STIKES Suaka Insan \\ *Email : teresiaivana@gmail.com
}

\begin{abstract}
ABSTRAK
Virus corona merupakan virus jenis baru yang dilaporkan muncul di Wuhan pada 12 Desember 2019, kemudian diberi nama Severe Acute Respiratory Syndrome Coronavirus 2 (SARS-COV2) dan menyebabkan penyakit Coronavirus Disease 2019 (Covid-19). Angka kejadian penyebaran infeksi virus terus meningkat termasuk di Indonesia. Bahkan World Health Association (WHO) menyatakan keadaan darurat dunia atas kejadian ini.

Pemerintah melalui perannya terus menerus menghimbau kepada masyarakat untuk bisa menjalankan protokol kesehatan seperti menjaga jarak, mengenakan masker dan mencuci tangan dikegiatan sehari-harinya. Akan tetapi, merubah kebiasaan perlu waktu yang cukup panjang akan menjadi kebiasaan baru. Salah satu yang harus mencoba menerapkan kebiasaan baru adalah mahasiswa suatu perguruan tinggi, karena jumlah dan peran mereka sangat tinggi di lingkungan masyarakat.

Metode pengabdian masyarakat yang dijalankan oleh tim pengabdi adalah dengan penyuluhan kesehatan tentang New Normal pada mahasiswa/I Keperawatan STIKES Suaka Insan Banjarmasin melalui aplikasi conference yaitu Google Meet.

Hasil dari pengabdian masyarakat didapatakan semua mahasiswa telah mengetahui dengan baik tujuan dari menjalani kebiasaan baru atau new normal. Dari kegiatan ini diharapkan mahasiswa dapat menjadi penyebar informasi bagi kelompok masyarakat lainnya tentang kebiasan baru atau new normal.
\end{abstract}

Kata Kunci : New normal, pandemi, covid 19

\section{A. PENDAHULUAN}

Coronavirus memiliki jenis baru yang disebut Corona Virus Disease 2019 (Covid19). Covid-19 pertama kali diidentifikasi di kota Wuhan. Pada saat ini Covid-19 dinyatakan sebagai keadaan darurat dunia oleh WHO (Tandra, 2020). Tanda gejala terinfeksi Covid-19 cukup bervariasi, dari yang ringan tanpa gejala hingga gejala yang parah. Gejala umum yang timbul saat terpapar virus Covid-19 seperti gangguan pernapasan akut, sesak napas, demam, batuk, tubuh terasa pegal-pegal, mual muntah, dan diare (Pennington, 2020). Pada kasus yang parah dapat terjadi pneumonia, sindrom pernapasan akut, gagal ginjal bahkan kematian. Tanda dan gejala klinis yang dilaporkan pada sebagian besar kasus adalah demam dengan mengalami sesak napas dan hasil rontgen menunjukkan infiltrat pneumonia di kedua paru (Pedoman Pencegahan dan Pengendalian Covid-19, 2020).

Kenormalan baru atau new normal adalah membuka kembali aktivitas ekonomi, sosial dan kegiatan publik secara terbatas dengan tetap menggunakan protokol kesehatan terkait COVID-19. Perubahan 
perilaku atau yang disebut Kenormalan Baru adalah sesuatu yang dianjurkan WHO untuk dilakoni. Beradaptasi dan hidup berdampingan dengan corona bukan sesuatu yang mudah. Masyarakat tidak dapat melanjutkan pola hidup normal sebelumnya, tetapi harus ada Kenormalan Baru (Puslitbang Kemensos, 2020).

Kepatuhan terhadap protokol kesehatan merupakan kunci utama untuk memutus rantai penyebaran covid-19. Berbagai kebijakan ataupun himbauan pemerintah diabaikan atau tidak dipatuhi. Himbauan menjaga jarak, memakai masker, mencuci tangan secara teratur dengan sabun atau disinfektan. Mahasiswa merupakan salah satu agen pembawa perubahan dan sebagai pengontrol kehidupan sosial dari dampak yang telah timbul dimasa pandemi. Mahasiswa banyak melakukan aktivitas di luar rumah, kerumunan mahasiswa juga tampak di mana-mana. Salah satunya yaitu budaya nongkrong di tempat keramaian baik di cafe-cafe, mall, tempat hiburan, taman Kota, serta mereka tidak menghindari kontak fisik ketika bertemu (Tuwu, Darmin, 2020).

Hasil penelitian Gugus Tugas Penanganan COVID-19 Universitas Lambung Mangkurat Banjarmasin (2020), mendapatkan bahwa masih banyak mahasiswa yang tidak patuh terhadap protocol kesehatan. Kebanyakan mahasiswa juga hanya mampu menerapkan penggunaan masker, dibandingkan menjaga jarak dan mencuci tangan

\section{B. METODE}

Metode yang digunakan adalah melalui google meeting. Dengan acara sebagai berikut:

1. Persiapan dalam meeting room Aplikasi Google Meet

2. Peserta masuk meeting room

3. Presensi Google form

4. Pembukaan dan doa Pembukaan

5. Pemaparan materi

6. Kenormalan Baru

7. Video cuci tangan pakai sabun

\section{Hasil dan Pembahasan}

Kegiatan pengabdian masyarakat terkait Kenormalan Baru adalah masyarakat di lingkungan sekitar STIKES Suaka Insan Banjarmasin terlaksana pada hari Rabu, 20 Mei 2020 secara daring menggunakan aplikasi Google Meet. Hal tersebut dilakukan sesuai prosedur COVID-19, yang tidak mengijinkan pertemuan dengan banyak orang dalam satu waktu dan tempat. Peserta adalah 54 masyarakat di lingkungan STIKES Suaka Insan Banjarmasin dengan rentang usia 19 s.d 44 tahun.

Mahasiswa merupakan merupakan satu agen pembawa perubahan dan sebagai pengontrol kehidupan sosial dari dampak yang telah timbul dimasa pandemi (Tuwu, 
Darmin, 2020). Akan tetapi, masih banyak mahasiswa yang belum patuh terhadap protokol kesehatan. Padahal cara ini merupakan salah satu cara ampuh dalam menangani penyebaran virus. Hal ini dikarenakan, belum ditemukannya antiviral spesifik yang dapat digunakan sebagai vaksin hingga saat ini (Gennaro, et al, 2020).

Penyuluhan kesehatan tentang kebiasaan baru merupakan salah satu cara mengedukasi kelompok masyarakat untuk dapat berubah sesuai pengetahuannya. Dimana, Notoatmodjo (2012), juga menguraikan bahwa perilaku kesehatan seseorang dipengaruhi oleh tingkat pengetahuannya.

Melalui peningkatan pengetahuan ini diharapkan perilaku mahasiswa dalam menerapkan protokol kesehatan akan lebih baik lagi. Mahasiswa akan menjadi agen perubahan sikap dan perilaku baru dimasa pandemi ini. Melalui perannya juga mahasiswa diharapkan dapat menjadi penyebar informasi yang benar terkait new normal ke masyarakat yang lebih luas.

\section{Kesimpulan}

Kenormalan Baru menjawab ketidaktahuan masyarakan selama ini, sehingga setelah penyuluhan mereka dapat memahami protokol apa saja yang dilakukan untuk dapat berdampingan dengan COVID-19. Penyelenggara menyarankan kepada peserta untuk mulai membiasakan diri untuk selalu memakai masker saat di luar rumah, rajin mencuci tangan, menjaga jarak aman, dan bila memungkinkan dapat bekerja atau beraktivitas di rumah saja selama Pandemi COVID-19

\section{DAFTAR PUSTAKA}

Adam, M. 2020. Asuhan Keperawatan pada Pasien dengan Covid-19. Departemen KMB FIK UI IGD RSUI. Jakarta

Bulecheck, Gloria M, dkk (Ed). 2013. Nursing Intervention Classification (NIC) 6th Edition. Missouri: Elsevier.

2020. Buku Saku Desa Tangguh
COVID-19 versi I (140420).
Yogyakarta. Universitas Gadjah Mada
Gugus Tugas Penaganan Covid-19 ULM
(2020), Covid19.ulm. ac.id

Herdman, T. Heather (Ed). 2012. NANDA International: Nursing Diagnosis 20122014. Oxford: Wiley

Majumder, N. 2016. Physiology of Respiration. IOSR Journal of Sports and Physical Education

Moorhead, Sue, dkk (Ed). 2013. Nursing Outcomes Classification (NOC) 5th Edition.Missouri: Elsevier.

Notoatmodjo. (2012). Promosi Kesehatan dan Perilaku Kesehatan. Jakarta: Rineka Cipta.

Patwa, A and Shah, A. 2015. Anatomy and Physiology of Respiratory System Relevant to Anaesthesia. Indian Journal of Anaesthesia

Pokja Infeksi Saluran Reproduksi. 2020. Rekomendasi Penanganan Infeksi Virus Corona (COVID-19) pada Maternal 
(Hamil, Bersalin dan Nifas). POGI. Jakarta

Tim Kerja Kementerian Dalam negeri untuk Dukungan Gugus Tugas COVID-19. 2020. Pedoman Umum menghadapi Pandemi COVID-19 bagi Pemerintah Daerah: Pencegahan, Pengendalian, Diagnosis dan Manajemen. Jakarta

Tuwu, Darmin, (2020.) Dilema Penanganan Covid-19: Antara Legitimasi Pemerintah Dan Kepatuhan Masyarakat. Vol 1 No1 . Jurnal Kesejahteraan dan pelayanan Sosial, 90-97 Diaskses tanggal 10 Oktober ; 10;12 PM, http://ojs.uho.ac.id

WHO.2020. Tata Laksana Klinis Infeksi Saluran Pernapsan Akut Berat (SARI) Suspek Penyakit COVID-19. Jakarta 